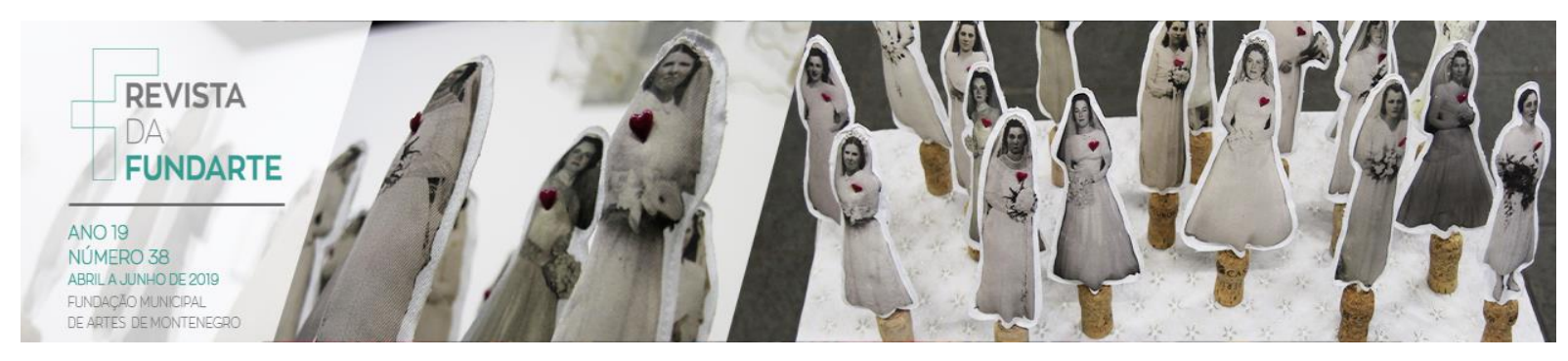

\title{
TEXTO SÉRIES GRÁFICAS IV
}

Leila Groth Ibarra' Anna Paula Rodrigues da Rosa²

Unindo os trabalhos plásticos das artistas gaúchas, Anna Rosa e Leila Groth Ibarra, a exposição Séries Gráficas IV: \{Re\}costurando o feminino conta com a produção de obras híbridas, elaboradas a partir de diferentes linguagens artísticas, como gravura, fotografia, desenho, costura, bordado e crochê. A convergência das produções reside na utilização da linha, de processos manuais tradicionalmente considerados femininos, questionando-os e ressignificando-os por meio da arte. No âmago dos trabalhos plásticos se encontram questões sensíveis ao feminino, com ênfase em temas como corpo, gênero e identidade social.

Os trabalhos de Anna Rosa permeiam temas dicotômicos, como afetividade e desapego, obediência e subversão, fragilidade e força. No trabalho "Grandes Meninas, Pequeno Mundo", a artista retrata três figuras de meninas de diferentes épocas - Anne Frank, Claudette Colvin e Malala Yousafzai -, que, no início de suas adolescências, tiveram a coragem de expor suas ideias em um mundo que teme 0 empoderamento feminino. Em "Felizes para sempre?", noivas das décadas entre 30 e 60 se transformam em pequenas bonecas que carregam em seu peito um coração

\footnotetext{
${ }^{1}$ Graduada em Artes Visuais pela Universidade Feevale (2016). Atua como artista visual e curadora. Entre as principais técnicas exploradas estão pintura, desenho, gravura, assemblagem e instalação. Sua produção aborda corpo, visceralidade e acúmulo, trabalhando com processos híbridos. O foco dos seus trabalhos artísticos está no corpo feminino, incorporando materiais e atividades tradicionalmente consideradas parte do universo feminino para ressignificá-los por meio da arte. Visa questionar os padrões impostos às mulheres, principalmente relativos à anatomia feminina, com intuito de naturalizar, desmistificar e desobjetificar eles. Participa do Coletivo Mariposa (2013 atual), cujo foco é ressignificar contos de fadas por meio de obras contemporâneas, produzindo trabalhos com viés feminista que questiona conceitos ligados à feminilidade.

2 Possui graduação em Artes Visuais pela Universidade Feevale (2016). Trabalha como designer, ilustradora freelancer e artista visual. Tem experiência na área de Artes Visuais, onde seu foco são os desdobramentos mestiços entre a gravura, desenho, pintura, vídeo e fotografia. Desde 2013 participa do Coletivo Mariposa, coletivo de arte que ressignifica contos de fadas através de obras contemporâneas, produzindo trabalhos com um viés feminista que questiona conceitos ligados à feminilidade.
}

IBARRA, Leila Groth; DA ROSA, Anna Paula Rodrigues. Texto Séries Gráficas IV. Revista da FUNDARTE, Montenegro, p.225-227, ano 19, no 38, abril/junho de 2019.

Disponível em: http://.seer.fundarte.rs.gov.br/index.php/RevistadaFundarte/index> 28 de junho de 2019. 


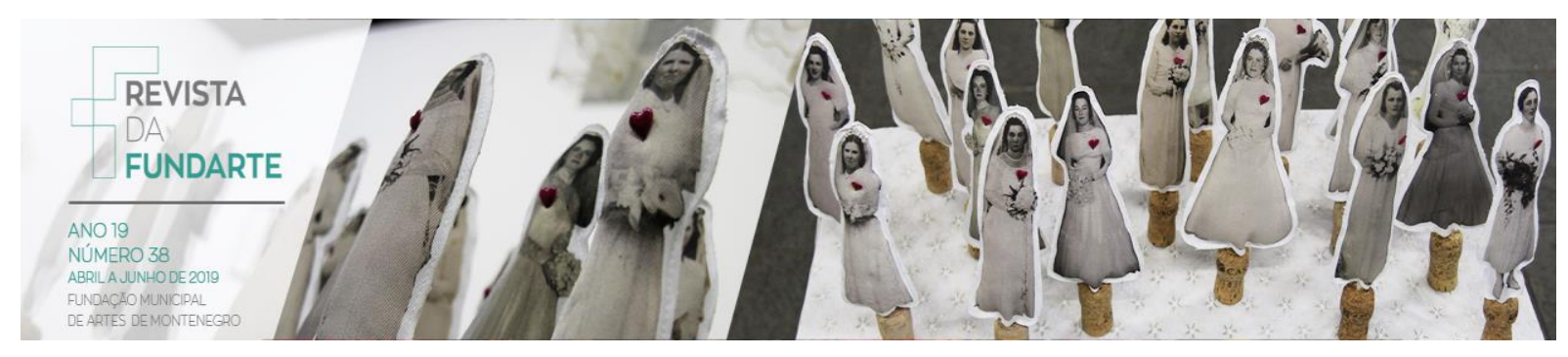

vermelho que transborda a esperança febril da felicidade eterna. O trabalho "Em Conserva" traz corações guardados em potes de vidros, escondidos sob memórias, perdas, amores e desamores, remendos e palavras perdidas. As figuras femininas, em "Renda-se",impressas sob a renda branca, trazem a dualidade entre a fragilidade do material utilizado e a força na expressão das mulheres retratadas.

A produção artística de Leila Groth Ibarra aborda partes do corpo feminino que são marginalizadas, ignoradas e, ao mesmo tempo, objetificadas dentro da sociedade, tornando-os plásticos e impondo padrões inalcançáveis que subjugam as mulheres. No tríptico "Florescer", aborda os pelos das axilas e virilha, os quais, em mulheres, são percebidos como sujos e desnecessários - para questionar essa percepção, os pelos são apresentados como jardins florescendo; ainda na mesma série, traz os mamilos, também polêmicos e censurados, o contrário do que ocorre tanto com mamilos quanto com pelos masculinos - e, como com os pelos, estes são mostrados florindo. A série "PPKs" conta com mais de 50 vulvas de crochê, feitas manualmente pela artista, e visa celebrar a diversidade natural da genital feminina. Os 5 trabalhos que constituem "Bastidores Transbordados" apresentam algumas partes da anatomia feminina como forma de desmistificar, desobjetificar e dar visibilidade ao corpo da mulher, aplicando o sangue menstrual na produção para intensificar essa proposta, assim como o bordado - ambos ressignificados por meio da arte. Por fim, "Traços Gerativos" propõe-se a fazer uma ligação entre gerações de mulheres por meio do bordado, com intervenções da artista sobre uma fronha bordada por sua bisavó. 